\title{
FATHER'S ROLES ON THE EXCLUSIVE BREASTFEEDING PRACTICE
}

\author{
Izzatul Arifah, Dina Rahayuning P., Moh. Zen Rahfiludin \\ University of Diponegoro, Semarang \\ e-mail: izzatularifah@gmail.com
}

\begin{abstract}
Background: Exclusive breastfeeding is the best way feed infant aged 0-6 months. Various factors influence breastfeeding practice, include father's role factors. This study aimed to describe father's roles and its association to breastfeeding practices.

Method: Method used in this study was survey with cross sectional approach. The sample were 80 couples who had 0-6 month aged baby lived in the service area of Ngesrep subdistrict in February 2012 using pusposive sampling technique. Data were analyzed descriptively using chi-square statistical test.

Result: The result showed among mothers with exclusive breastfeeding practice, about $80 \%$ father did support their wife. Father's role were significantly associated to exclusive breastfeeding practices $(\mathrm{p}=0.0001)$. It was also influenced by medical support $(\mathrm{p}=0.042)$, grand mother and peer support ( $\mathrm{p}=0.0001)$, and non-working mothers $(\mathrm{p}=0.049)$.

Conclusion: Fathers who did role supporting mothers to practice exclusive breastfeeding, improve its success. However, medical support, grand mother and peer support, and mother's occupation are confounding variable for this.
\end{abstract}

Keywords: exclusive breastfeeding, father, father's role

\section{Introduction}

Since 2002 the WHO-UNICEF states that exclusive breastfeeding for the first 6 months is the best way to feed a baby. ${ }^{1}$ However, until now exclusive breastfeeding practice is rarely performed according to the recommendations and even tended to decrease from year to year. The data show, based on the results of Indonesia Demographic Health Survey (IDHS) 2002-2003 practice of exclusive breastfeeding at $39.5 \%$, the results obtained in 2007 IDHS exclusive breastfeeding practice decreased to $32 \%$ and based on the results of Health Research (Riskesdas) in 2010, the practice of exclusive breastfeeding in Indonesia decreased alot at $15.3 \%{ }^{2,3}$ Exclusive breastfeeding is well known for the benefit to infants's health and optimalization of development, benefit for Mother's health and economic benefits. ${ }^{4,5}$ The Indonesian government has given support to improve practice of exclusive breastfeeding since 2004 with the Decree of the Minister of Health of the Republic of Indonesia number 450/Menkes/SK/IV/2004. ${ }^{6}$ However, it doesn't enough to help improving exclusive breastfeeding practice for 6 months. Various factors has been associated exclusive breastfeeding practices, among of those are implementation of Early Initiation of Breastfeeding, the promotion of exclusive breastfeeding/infant formula by health profesional, the support from health care facilities, support from family and peer, and especially her husband. ${ }^{5,7-10}$

The role of the husband or father of the baby at this time, was more elaborated since some studies said that the breastfeeding relationship is seen not only between mothers and infants, but is a triad relationship of mother, baby, and father. ${ }^{9,10}$

Prior studies show there are relationship between father's level of knowledge and attitudes about breastfeeding and exclusive breastfeeding practice. Mothers who 
had longer duration of exclusively breastfeeding, her husband has a good level of knowledge and a great attitude as well. ${ }^{11,12}$ Emotional, practical and physical support from father, is necessary to increase the success of exclusive breastfeeding. ${ }^{13}$ Furthermore, Februhartanty in qualitative studies in urban areas of Jakarta, stated that father have had play an importance role in the mother's exclusive breastfeeding practice. Father's roles are grouped into 6 main role that thought to be associated with exclusive breastfeeding practice. ${ }^{14}$ Through this study, researcher wanted to see how father's role in exclusive breastfeeding practice and how those practices, that were known relevant to breasfeeding could influence exclusive breastfeeding practice, especially in the middle socioeconomic population in the city of Semarang, which is at the Puskesmas Ngesrep.

\section{Research Method}

Method used in this research was survey, with descriptive correlative and Cross Sectional approach. Samples taken in this study was 80 couples who had a 0-6 month aged baby in the service area of Ngesrep Primary Health Care, Semarang city from 143 couples in population in January-February 2012. Method used was non-probability sampling with purposive sampling at Posyandu that had the highest number of babies 0-6 months, divided into 5 Posyandu units in the Sumurboto, 3 in Ngesrep and 3 in Tinjomoyo. All respondents of this study have met the inclusion criteria, as follows: 1 ) Mother breastfed her babies; 2) Mother lived at the same house with baby and husband; 3) Mother is not in a state of disease that was breastfeeding's contraindication (tuberculosis, cardiac disease, and HIV-AIDS, etc.); 4) Normal babies, without congenital abnormalities; 5) Babies are not premature and low birth weight; and 6) the couple is willing to be a respondents in this study.

The instrument used in this study was a questionnaire based on a literature review. Information of characteristics of the respondents (baby, mother and father), family characteristics, breastfeeding practices and confounding variables (support health workers, grandmother and friend support, information about exclusive breastfeeding) was obtained from interviews with mothers. Mothers who said give only breast milk to her baby aged 0-6 months in the past 24 hours, from birth to time of the research and the baby does not get liquids or other solids before breast-fed was catagorized as exclusive breastfeed. Support grandmother and friend in this study was mother who obtained support for breastfeeding in the form of suggestions to the mother. Medical support in this study was mother who obtained the support from health professionals to give breast milk in the form of suggestions through counseling during pregnancy, childbirth, postpartum and prelakteal feeding practices in infants. Exposure to information of exclusive breastfeeding means mother have exposured to information about exclusive breastfeeding in mass media such as newspapers, magazines, Internet, and books on exclusive breastfeeding. Information about father's role was obtained by interview with the father.

Father's roles means the practices carried out by a father which were performed during pregnancy, childbirth and lactation, that are associated with exclusive breastfeeding practiced by mothers, include: 1) The role of seek information about infant feeding; 2) The involvement of decision-making about infant feeding; 3) Enggangement in labor; 4) Positive attitude towards marriage, and 5) Involvement in varoius activity of child care. The questionnaire has been tested through a valid and reliable test questionnaires to the respondents with the same criteria in the research area. The data is then displayed in form of cross-tabulation and Chi-Square test were used to find the correlation between variables, using $5 \%$ significance level. 


\section{Result and Analysis}

\subsection{Characteristics of Respondents}

The age of youngest mothers in this study was 17 years old and the oldest was 43 years. Based on table 1, the whole mother was literate and the majority of them have completed primary education which is high school graduates (55\%). Most mothers did not work $(60 \%)$, and a mother who worked mostly in the private sector as employees $(26.2 \%)$. Youngest paternal age in this study was 20 years old and the oldest was 43 years. The whole father also literate and the majority have completed primary education which is high school graduates $(66.2 \%)$. The whole father worked, and most of them work on the private sector as employees (48.8\%). Others (13.8\%) was informal sector workers, such as laborers, and the driver.

The most babies in this study was at 3-4 months aged (41.2\%) and most were female (55.0\%). Most couples live with grandma, grandpa, aunts and uncles of baby, so they were lived in extended families (72.5\%). Family income was in the range of at most $\mathrm{Rp} 500.000$ - Rp 1.000 .000 (37.5\%). Most of family income of more than $\mathrm{Rp} 1.000 .000$. By education level and family income level then respondents categorized as sosio-economic middle class. 
Tabel 1. Characteristic of Respondents $(n=80)$

\begin{tabular}{|c|c|c|}
\hline Characteristic of Respondents & Number & Percentage (\%) \\
\hline \multicolumn{3}{|l|}{ Mother } \\
\hline \multicolumn{3}{|l|}{ a. Educational } \\
\hline Elementary School & 8 & 10.00 \\
\hline Junior Highschool & 7 & 8.80 \\
\hline Senior Highschool & 44 & 55.00 \\
\hline Diploma/University degree & 21 & 26.20 \\
\hline \multicolumn{3}{|l|}{ b. Occupation } \\
\hline Not working & 48 & 60.00 \\
\hline Civil Cervants & 1 & 1.20 \\
\hline Interpreneur & 10 & 12.50 \\
\hline Employee & 21 & 26.20 \\
\hline Others & 0 & 0 \\
\hline \multicolumn{3}{|l|}{ Father } \\
\hline \multicolumn{3}{|l|}{ a. Educational } \\
\hline Elementary School & 6 & 7.50 \\
\hline Junior Highschool & 1 & 1.20 \\
\hline Senior Highschool & 53 & 66.20 \\
\hline Diploma/University degree & 20 & 25.00 \\
\hline \multicolumn{3}{|l|}{ b. Occupation } \\
\hline Not working & 0 & 0 \\
\hline Civil Cervants & 9 & 11.20 \\
\hline Interpreneur & 21 & 26.20 \\
\hline Employee & 39 & 48.80 \\
\hline Others & 11 & 13.80 \\
\hline \multicolumn{3}{|l|}{ Baby } \\
\hline \multicolumn{3}{|l|}{ a. Age (Month) } \\
\hline $0-2$ & 23 & 28.80 \\
\hline 3-4 & 33 & 41.20 \\
\hline $5-6$ & 24 & 30.00 \\
\hline \multicolumn{3}{|l|}{ b. Sex } \\
\hline Female & 44 & 55.00 \\
\hline Male & 36 & 45.00 \\
\hline \multicolumn{3}{|l|}{ Family } \\
\hline \multicolumn{3}{|l|}{ a. Family income } \\
\hline$\leq \operatorname{Rp} 500.000$ & 6 & 7.50 \\
\hline Rp 500.000 - Rp 1.000 .000 & 30 & 37.50 \\
\hline Rp 1.000.000 - Rp 2.000.000 & 22 & 27.50 \\
\hline$\geq \operatorname{Rp} 2.000 .000$ & 22 & 27.50 \\
\hline \multicolumn{3}{|l|}{ b. Family's Characteristic } \\
\hline Nucleus family & 22 & 27.50 \\
\hline Extended family & 58 & 72.50 \\
\hline
\end{tabular}

\subsection{Exclusive Breastfeeding Practice}

Exclusive breastfeeding is feeding practices for infants begins at birth due to time of research carried out, include of this is practice of breastfeeding initiation, prelakteal feeding practices, and the practice of exclusive breastfeeding until 6 month. Based on Table 2 most mothers initiate breastfeeding in less than 1 hour (68.8\%). Most of the infants in this study did not receive any food prelakteal before obtaining breast milk (66.2\%). However there are $33.8 \%$ of the infants who received prelakteal foods such as formulas and sugar water before get breastfeed. Prelakteal feeding is mostly done by family and mostly with the approval of their doctor/ midwife/nurse in the health service. 
Tabel 2. Exclusive Breastfeeding Practice

\begin{tabular}{ccc}
\hline Exclusive Breastfeeding Practice & $\begin{array}{c}\text { Number(n=80) } \\
\text { (person) }\end{array}$ & $\begin{array}{c}\text { Persentage } \\
(\%)\end{array}$ \\
\hline Time initiation & & \\
$\leq 1$ hour & 55 & 68.80 \\
>1 hour & 25 & 31.20 \\
Prelacteal Feeding & 53 & 66.20 \\
No Prelacteal feeding & 26 & 32.50 \\
Formula & 1 & 1.30 \\
Sugar water & & \\
Breastfeeding practice (past 24 hours) & 31 & 38.80 \\
Exclusive breastfeeding & 49 & 61.20 \\
Non exclusive breastfeeding &
\end{tabular}

Percentage of exclusive breastfeeding presented in this study using two definitions to analyze the differences in the use of these definitions. Results are shown using the WHO's definition as in the practice of breastfeeding in the past 24 hours the percentage obtained exclusive breastfeeding is at $38.8 \%$, when using the definition of breastfeeding in the past 24 hours, from birth until now, and do not get prelakteal food, as used in Riskesdas, the percentage of exclusive breastfeeding were at $31.2 \%$, so there is a $7.6 \%$ differences. It shows that there are $7.6 \%$ of infants were failed to exclusively breastfed because prelakteal fed. The more dominant role in a few hours after birth is from health profesional. Practices of health profesional that support exclusive breastfeeding, such as food deprivation prelakteal, doing rooming in, so can mothers breastfeed more often, and also provide counseling on exclusive breastfeeding and breastfeeding techniques, can help mother to successfully deliver exclusive breastfeeding. ${ }^{14}$

\subsection{Father's roles}

Father's roles to support breastfeeding have been started from pregnancy, childbirth, breastfeeding till it lasts. Those father's role include role of seeking information about infant feeding, involvement in decision making to feed children, engaged in labor, have a positive attitude in marriage, and involved in various activities of child care. Father performed a variety of roles are described in Table 3.

The role of seek information was conducted by $16.2 \%$ father. Seeking information about breastfeeding is the basic role that should be done by the father's in order know about breastfeeding so he can support mothers breastfeed exclusively. ${ }^{14}$ But in contrary this was the most rare roles done by father. A total of $55 \%$ of fathers knew that breast milk is the best food for babies 0-6 months aged, and the information was largely derived from an ancestor or relative (family) (51.2\%) and health profesional (25\%). But only $22.5 \%$ father then tried to find information about breastfeeding to get a better knowledge about it. Thats shows, most of the father passive in seeking of information about breastfeeding. Families and health profesional who was father's resources of information, if they were not support exclusive breastfeeding and gave wrong information about it, would lead father have a wrong perception about breastfeeding.

The role involved in decision-making of infant's feeding was done by $23.8 \%$ father. Based on the theory, fathers played a major role in decisionsmaking about family and domestic affairs. Father usually had an authority on various aspects of family life including intra-household aspects. ${ }^{15}$ However, the 
results from this study was deference. Mothers is a person in charge at everything related to child care. In accordance with previous studies, most of the fathers said that for the child's care father handed over responsibility to mother. ${ }^{14}$ Mother considered already knew how to take care an infants, and gave them a good meal, especially if they were not the first child.

Tabel 3. Father's role on the exclucive breastfeeding practice

\begin{tabular}{|c|c|c|c|c|}
\hline $\begin{array}{l}\text { Father's role } \\
\text { Ayah }\end{array}$ & $\begin{array}{l}\text { Yes } \\
\text { (n) }\end{array}$ & $\begin{array}{c}\text { Persentage } \\
(\%)\end{array}$ & $\begin{array}{l}\text { No } \\
(\mathrm{n})\end{array}$ & $\begin{array}{c}\text { Persentage } \\
(\%)\end{array}$ \\
\hline \multicolumn{5}{|l|}{ Role of seeking information } \\
\hline Right perception about breastfeed & 44 & 55.0 & 36 & 45.0 \\
\hline Seeking information about breastfeed & 18 & 22.5 & 62 & 77.5 \\
\hline \multicolumn{5}{|l|}{$\begin{array}{l}\text { Role involved in decision-making of } \\
\text { infant's feeding }\end{array}$} \\
\hline Involved in decision making & 35 & 43.8 & 45 & 56.2 \\
\hline Giving correct advise & 32 & 40.0 & 48 & 60.0 \\
\hline \multicolumn{5}{|l|}{ Role involved in delivery process } \\
\hline Selection of delivery place & 47 & 58.8 & 33 & 41.2 \\
\hline Enganged in labor & 26 & 32.5 & 54 & 67.5 \\
\hline Knowledge about Early Initiation & 27 & 33.8 & 53 & 66.2 \\
\hline \multicolumn{5}{|l|}{ Having positive attitude in marriage } \\
\hline Accompany in ANC & 58 & 72.5 & 22 & 27.5 \\
\hline Enter the examination room & 46 & 57.5 & 34 & 42.5 \\
\hline Accompanying if the baby cries at night & 57 & 71.2 & 23 & 28.8 \\
\hline Efforts of swittning breastfeeding & 60 & 75.0 & 20 & 25.0 \\
\hline $\begin{array}{l}\text { Afection to the mother when she doing } \\
\text { breastfeed }\end{array}$ & 53 & 66.2 & 27 & 33.8 \\
\hline The division of household task & 51 & 63.8 & 29 & 36.2 \\
\hline \multicolumn{5}{|l|}{ Roles involved at child care } \\
\hline Daily baby care & 62 & 77.5 & 18 & 22.5 \\
\hline Nurturing baby & 62 & 77.5 & 18 & 22.5 \\
\hline
\end{tabular}

The role involved in the delivery process was done by $40 \%$ of fathers. This study shows, only $32.5 \%$ the father who accompanied the birth process. Various reasons were explain to their absence in delivery process, such as take care the sisters or brothers, have another job at that time, and even some father said that the they did not want to, afraid or shame. However, important to be noted that $44.4 \%$ of fathers who did not accompany mother in delivery process was because banned by health workers. This is the contrary, health workers should guide father to raises his role as father through delivery process, in addition, they also should know better the benefits of a father's presence in the delivery process than others.

The most role perfomed by fathers were involved in child care and had a positive attitude to marriage. Previous studies about the role of the father, this two roles were also a common role performed by father. ${ }^{14} \mathrm{~A}$ positive attitude to marriage was shown by the concern for the mother and baby, as well as good cooperation between mom and dad. The quality of the marital relationship was an important predictor of the success of breastfeeding. ${ }^{16}$ Prior study stated that a positive attitude to marriage was significantly associated with exclusive breastfeeding. ${ }^{14}$ Most of the fathers in the study had perfomed well this role. But there was still a $30 \%$ fathers who did not. Most couples assumed that the division of household tasks was clear that father as the wage earner, and a mother as a care taker. It shows that there were some families that are culturally had a straight division of task domain between men and women. ${ }^{14}$ 
Each of these roles did by fathers then categorized into support and do not support exclusive breastfeeding. Total roles performed by the father can be described in the following.

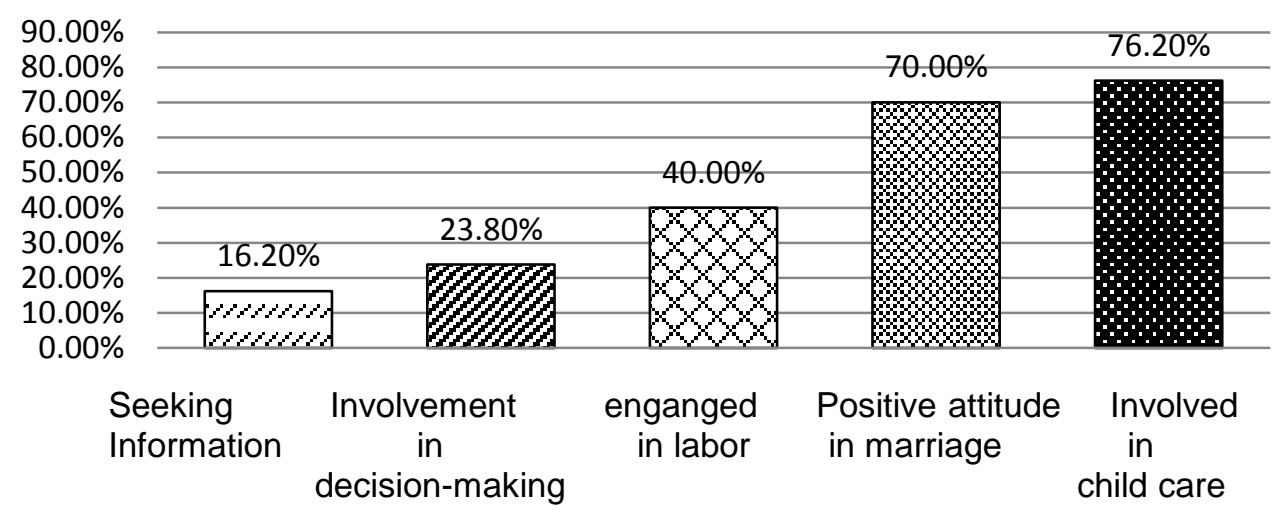

Figure 1. Father's role on the exclusive breatsfeeding practice

\subsection{Father's role on the exclusive breatsfeeding practice}

Overall, the majority of fathers did not perform roles that support exclusive breastfeeding practice. Only $42 \%$ of fathers who did support. Table 4 shows the percentage of mothers who exclusively breastfed was higher in the group of fathers who did supporting roles, than not, that is $58.8 \%$ compared to $10.9 \%$, and vice versa. Bivariate analysis found a significant association between father's role with exclusive breastfeeding practice $(p=0.0001)$.

Tabel 4. Cross tabulation of exclusive breastfeeding practice based on father's role

\begin{tabular}{ccccccc}
\hline \multirow{2}{*}{ Father's role } & \multicolumn{2}{c}{$\begin{array}{c}\text { Non exclusive } \\
\text { breastfeeding }\end{array}$} & \multicolumn{2}{c}{ exclusive breastfeeding } & \multicolumn{2}{c}{ Total } \\
\cline { 2 - 7 } & Number & $\begin{array}{c}\text { Persentage } \\
(\%)\end{array}$ & Number & $\begin{array}{c}\text { Persentage } \\
(\%)\end{array}$ & $(\mathrm{n})$ & $(\%)$ \\
\hline Not support & 41 & 89.1 & 5 & 10.9 & 46 & 100 \\
Support & 14 & 41.2 & 20 & 58.8 & 34 & 100 \\
\hline
\end{tabular}

$\left(x^{2}=20.925, p=0.0001\right)$

This result is consistent with prior study which states that fathers play a role through participating in decision-making about breastfeeding, provide help when breastfeeding initiation, duration of breast-feeding and a risk factor for formula feeding..$^{10,14,16}$ In tripartid breastfeeding relationship, the father plays an important role. Father identified as most importance persons who can give encouragement and support for breastfeeding, after the spirit from baby itself. ${ }^{13}$

Father who did not sure of the milk produced is sufficient enough meet the needs of babies and didn't understand and perceive babies'cry as sign of hunger, finally advised mother to give formula as supplement. Mothers who dread to husband's commands could immediately follow the husband's suggestions, so finnaly mother gave formula as supplement. ${ }^{8}$ In this study suggests, some respondents who father did not support breastfeeding practice, 
at the time of the study had not been breastfeeding anymore, and replace it with formula and other foods.

This study shows that the role of the father associated with exclusive breastfeeding not only begins when the decision of breasfeed was made, but includes practices that support from pregnancy, childbirth, breastfeeding until the process begins.

Being able carry out such a role, fathers still faced many barriers. Barriers include the quality of the couple relationship, the characteristics of thefather's domain task, father burden as wage earner, and father's knowledge. ${ }^{16}$ Lack of access to information about exclusive breastfeeding and how to support these practices. ${ }^{14}$ Family's member as the closest person have the opportunity to influence father's practice in supporting exclusive breastfeeding.

Besides father's role to support, other support from grandmother and peer, support from health profesional and non-working mother also have significant association, as shows in Table 5. Family and supportive environment to support exclusive breastfeeding lead father performing such supporting roles.

Tabel 5. Bivariate analysis between exclusive breastfeeding and others variabel

\begin{tabular}{lcc}
\hline Variables & Value & Asymp. Sig (2-sided) \\
\hline Father's role & 20.925 & 0.000 \\
Medical support & $4.155^{\mathrm{a}}$ & 0.042 \\
Grand mother and peer support & $20.884^{\mathrm{a}}$ & 0.000 \\
Information about exclusive & $3.665^{\mathrm{a}}$ & 0.056 \\
breastfeeding & & \\
Mother's occupation & $3.879^{\mathrm{a}}$ & 0.049 \\
Characteristic of family & $1.318^{\mathrm{a}}$ & 0.251 \\
\hline
\end{tabular}

Beside that, health professionals also have an important role to provide information to the father, especially about the practice of breastfeeding, how to support breastfeeding mothers and handling problems in breastfeeding, so can help mothers to successfully give exclusive breastfeeding (Table 5). Nonworking mother does have a better chance successfully give exclusive breastfeeding. In conclusion, so that father being able to carry out such roles that support exclusive breastfeeding practice, required good support from family, health facilities and health profesionals, as well as local cultural environment.

\section{Conclusion}

Father's role were significantly associated with exclusive breastfeeding practices. That role involved role of seeking information about breastfeeding, involvement in decision making to feed children, engaged in labor, have a positive attitude in marriage, and involved in various activities of child care. Support health profesionals, grandmother and peer support, and mother's occupation is also associated with the exclusive breastfeeding practice and could be a confounding variable in this relationship.

Then this should be as consideration in implementing the government's program to improve exclusive breastfeeding practice by involving fathers. 


\section{Reference}

1. WHO, UNICEF and the Global Strategy on Infant and Young Child Feeding (GSIYCF), 2002. Available from: www.unicef.orgnutritionfilesFinalReportonDistribution.pdf.

2. BPS, Indonesia Demographic and Health Survey 2007, Calverton Maryland, USA: BPS and ORC Macro, 2007.

3. RISKESDAS, Riset Kesehatan Dasar 2010, Jakarta: Badan Penelitian dan Pengembangan Kesehatan, 2010.

4. Stanley L, Chung M, Raman G, Chew P, Magula N, DeVine D, et al, Breastfeeding and Maternal and Infant Health Outcomes in Developed Countries, Evidence Report/Technology Assessment number, vol.153, 2007.

5. Gibney J., Gizi Kesehatan Masyarakat, Jakarta: EGC, 2008.

6. Keputusan Menteri Kesehatan Republik Indonesia Nomor 450/SK/ IV tahun 2004 tentang Pemberian Air Susu Ibu (ASI) pada bayi Secara Eksklusif pada Bayi di Indonesia, 2004.

7. Nakao Y, Moji K, Honda S, Oishi K., Initiation of breastfeeding within 120 minutes after birth is associated with breastfeeding at four months among Japanese women: A selfadministered questionnaire survey, International breastfeeding journal, vol/no: 3(1), 2008.

8. Septiari A, JF, Bardosono S., Praktek dan sikap bidan terhadap kebijakan ASI eksklusif hingga 6 bulan: studi kualitatif di Jakarta Utara, Tesis, Jakarta: Universitas Indonesia, 2006.

9. Lawrence R, Lawrence R., Breastfeeding: A Guide for The Medical Profession, 7 ed. Philadelpia: Mosby Inc. 2005.

10. Bar-Yam N, Darby L., Fathers and breastfeeding: A review of literature, J Hum Lact,vol/no: 13(1), pp. 45-50, 1997.

11. Juherman Y., Pengetahuan, Sikap, dan Peranan Ayah Terhadap Pemberian ASI Eksklusif, Skripsi tidak diterbitkan, Bogor: Institut Pertanian Bogor; 2008.

12. Kemalasari, Pengaruh karakteristik istri dan partisipasi suami terhadap pemberian ASI eksklusif kecamatan sitalasari kota pematangsiantar, Tesis tidak diterbitkan, Medan: Universitas Sumatera Utara, 2008.

13. Tohotoa J, Maycock B, Hauck Y, Howat P, Burns S, Binns C., Dads Make A Difference: An Exploratory Study of Paternal Support for Breastfeeding in Perth, Western Australia, International breastfeeding journal, vol/no: 4(15), 2009.

14. Februhartanty J., Peran Ayah Dalam Optimalisasi Praktek Pemberian ASI: Sebuah Studi di Daerah Urban Jakarta, Disertasi, Jakarta: Universitas Indonesia, 2008.

15. Tan K., Factors associated with exclusive breastfeeding among infants under six months of age in peninsular malasia, International breastfeeding journal, vol/no: 6(2), 2011.

16. Februhartanty J, Muslimatun S, Septiari A., Fathers help to improve breastfeeding practice: can Indonesian fathers provide the same help?, Universa medicana, vol/no: 26(2), 2007. 
